\title{
Accuracy of clinical examination in the diagnosis of eyelid lesions
}

\section{Acurácia do exame clínico no diagnóstico de lesões palpebrais}

\author{
Luiz Angelo Rossato', Rachel Camargo Carneiro' ${ }^{1}$, Ahlys Miyazaki², Suzana Matayoshi
}

\begin{abstract}
Objective: To analyze the accuracy of the clinical examination in the diagnosis of eyelid lesions. Methods: From the observation of thirtyfive photos of benign and malignant eyelid tumors were presented to ophthalmologists, for each picture, it was asked 3 questions: 1) the lesion is malignant or not;2) if considered malignant, the probably histological type; and 3) the tumor is aggressive or not. The phisicians were divided into 9 groups, according to academic degree (time since graduation and Oculoplastics specialty or not). Answers were compared with the results of the histopathologic study of the surgically resected tumor. Results: In total, one hundred and six ophthalmologists were interviewed. The professional experience influenced the diagnosis of malignancy of the tumor, as the Group 1 (first year residents) had the lowest accuracy $(64.5 \%$ ), with lower estimated agreement (kappa $=0.13$ ), and Group 5 (graduated 5 years ago and with expertise in Oculoplastics) the highest accuracy $(77.3 \%)$, with better agreement (Kappa $=0.45)$, and presented the best parameters for other analyzed items. For the histological type diagnosis, accuracy was lower: group 1 had the worst performance, with $51.1 \%$ accuracy, while the best was for group 6 (graduated over 5 years and with expertise in Oculoplastics, 77.2\% ). As for the criterion of tumor aggressiveness, the results were closer among the different categories. Ophthalmologists trained longer and without expertise in Oculoplastics also showed a low diagnostic accuracy for malignancy and to determine the histological type of tumor. Conclusion: The low accuracy of clinical diagnosis of eyelid tumors in the groups above reinforces the need to improve ophthalmic oncology knowledge in these groups.
\end{abstract}

Keywords: Eyelid neoplasms/diagnosis; Eyelid neoplasms/pathology; Medical oncology; Health knowledge, atitudes, practice

\section{RESUMO}

Objetivo: Analisar a acurácia do exame clínico no diagnóstico de lesões palpebrais. Métodos: A partir da observação de trinta e cinco fotos de tumores palpebrais benignos e malignos que foram apresentadas a médicos oftalmologistas, para cada foto foram feitas 3 perguntas: 1) lesão maligna ou não? 2) se considerado maligno, o provável tipo histológico; e 3) tumor agressivo ou não? Os médicos foram agrupados em 9 grupos, de acordo com a formação profissional (tempo de formação e especialização ou não em Oculoplástica). As respostas foram comparadas com o resultado do exame histopatológico da peça retirada cirurgicamente. Resultados: No total, cento e seis médicos oftalmologistas participaram do estudo. A experiência do profissional influenciou no diagnóstico de malignidade do tumor, já que o grupo 1 (residentes de primeiro ano) apresentou a menor acurácia $(64,5 \%)$, com menor concordância estimada (Kappa $=0,13)$, e o grupo 5 (formados há 5 anos e especializados em Oculoplástica) a maior acurácia $(77,3 \%)$, com melhor concordância $($ Kappa $=0,45)$, além de apresentar as melhores medidas para os demais itens avaliados. Para diagnóstico do tipo histológico, a acurácia foi menor no grupo 1 que obteve o pior desempenho, com 51,1\% de acurácia, enquanto o melhor foi o grupo 6 (formados há mais de 5 anos e especializados em Oculoplástica, $77,2 \%$ ). Já para o critério de agressividade do tumor os resultados foram mais próximos entre as diferentes categorias. Os oftalmologistas formados há mais tempo e sem especialização em Oculoplástica também demonstraram baixa acurácia diagnóstica no diagnóstico de malignidade e na determinação do tipo histológico do tumor. Conclusão: A baixa acurácia no diagnóstico clínico de tumores palpebrais nos grupos acima referidos reforça a necessidade de melhorar o conhecimento em oncologia palpebral nesses grupos.

Descritores: Neoplasias palpebrais/diagnóstico; Neoplasias palpebrais/ patologia; Oncologia; Conhecimentos, atitudes e práticas em saúde

'Ophthalmology Department, Medical School of the São Paulo University, São Paulo/SP, Brazil.

${ }^{2}$ Student, Medical School of the São Paulo University, São Paulo/SP, Brazil.

Study conducted at the University Hospital of the São Paulo University, São Paulo/SP, Brazil.

The authors declare no conflicts of interest

Received for publication: 14/7/2014 - Accepted for publication: 28/8/2014

Rev Bras Oftalmol. 2014; 73 (6): 324-8 


\section{INTRODUCTION}

H istopathological examination is considered the gold standard in the diagnosis of tumours, but clinical examination remains important for ensuring correct treatment and an improved prognosis. ${ }^{(1,2)}$ The presentation and appearance of lesions are very variable and there may be similarities between benign and malignant lesions. ${ }^{(3)}$ Different tumours can develop in the periocular skin, and these lesions are often diagnosed and managed by ophthalmologists. The first concern is the possibility of a malignant tumour. ${ }^{(4)}$

The objective of this study was to assess the accuracy of clinical examination in the diagnosis of eyelid lesions by ophthalmologists at different stages of professional training and with different levels of experience in oculoplastic surgery.

\section{MethodS}

This study used 35 images of benign and malignant eyelid lesions. The photos were taken in the outpatient clinic of the University Hospital of the São Paulo University (HCFMUSP) using a high-resolution digital camera (960 x 720 pixels) and printed on high-quality Fujifilm photographic paper (CT-RS3 7028).

Participants answered a paper questionnaire with three questions on each lesion:

1. Is the lesion benign or malignant?

2. If malignant, what is the most likely histological diagnosis [basal cell carcinoma (BCC), squamous cell carcinoma (SCC), melanoma, sebaceous gland carcinoma, other]?

3. If malignant, is it aggressive (micronodular, infiltrative, or sclerodermiform BCC; SCC; melanoma; sebaceous gland carcinoma) or non-aggressive (superficial or nodular BCC)?

No time limit was imposed on the participants.

The final five photos were excluded to avoid respondent fatigue. The responses were compared with the gold standard (histopathological examination of the excised lesion).

Participants were grouped into 9 categories: first-year residents (Group 1), second-year residents (Group 2), third-year residents (Group 3); ophthalmologists specialised in oculoplastic surgery with 2, 5, or more than 5 years' experience (Groups 4, 5 and 6 , respectively); ophthalmologists not specialised in oculoplastic surgery with 2,5 , or more than 5 years' experience (Groups 7, 8 and 9, respectively).

The agreement between the interviewees' responses and the gold standard results for tumour malignancy and aggressiveness was calculated using the Kappa coefficient. Sensitivity, specificity, positive predictive value, negative predictive value, and accuracy were also calculated, as was the accuracy of respondents in determining the histological diagnosis. The confidence interval was set at $95 \%$. SPSS 15.0 software was used for statistical analysis.

The indicators used in the study are defined below: tive)

1. Sensitivity $=$ true positive/(true positive + false negative)

2. Specificity $=$ true negative/(true negative + false posi-

3. Positive predictive value $(\mathrm{PPV})=$ true positive/(true positive + false positive)

4. Negative predictive value $(\mathrm{NPV})=$ true negative $/$ (true negative + false negative)

5. Accuracy $=($ true positive + true negative $) /$ total

Results

In total, 27 malignant lesions (BCC, SCC, melanoma, sebaceous gland carcinoma) and 8 benign lesions (nevus, actinic keratosis, molluscum contagiosum, cutaneous horn) were presented to 106 ophthalmologists, grouped according to their professional experience and specialisation in oculoplastic surgery (Chart 1).

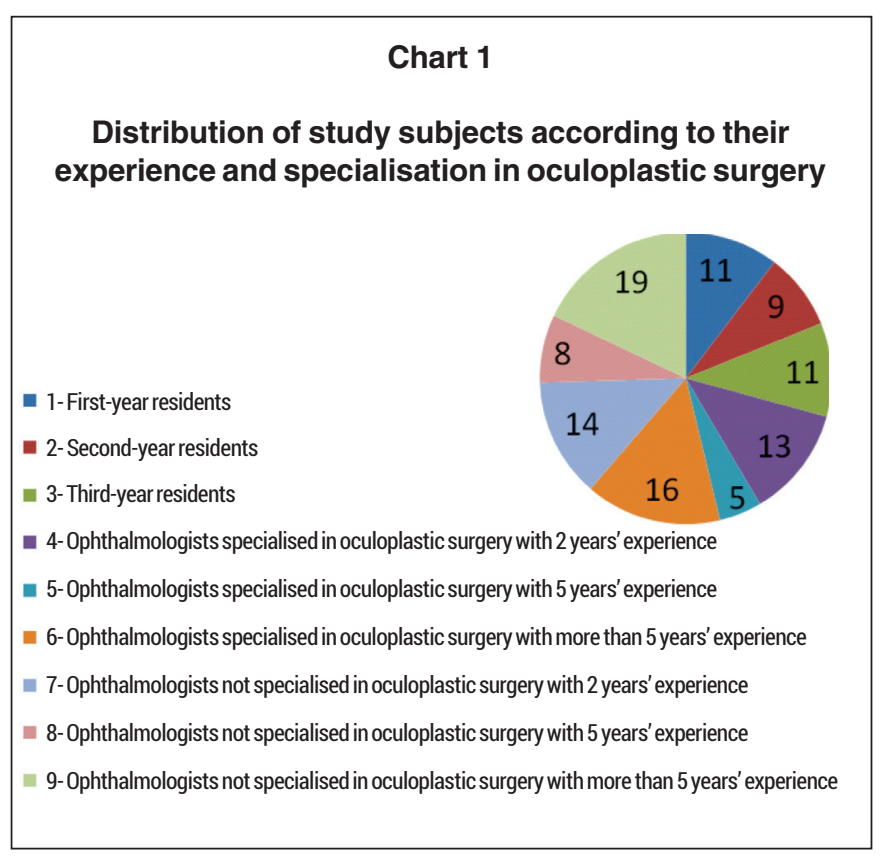

The level of experience of participants influenced their ability to diagnose malignancies: Group 1 was the least accurate $(64.5 \%)$ and had the lowest agreement $($ Kappa $=0.13)$, while Group 5 the most accurate $(77.3 \%)$ and had the greatest agreement $($ Kappa $=0.45)$ as well as the best results in the other items (Table 1). For malignancy, the overall accuracy of respondents was $68.2 \%$, with a sensitivity of $69.6 \%$, a specificity of $63.9 \%$, and a Kappa of 0.27 .

As regards the histological type, the overall accuracy was $63.3 \%$. Group 1 had the worst result with a $51.1 \%$ accuracy, whereas Group 6 had the best result (77.2\%) (Table 2).

For the criteria and categories mentioned above, the results of ophthalmologists not specialised in oculoplastic surgery were inferior to those of oculoplastic specialists, and the results improved with greater experience and specialisation in oculoplastic surgery. The mean overall accuracy for tumour aggressiveness was $74.2 \%$, with a sensitivity of $82.7 \%$, a specificity of $63.4 \%$, and a Kappa of 0.47 ; there was less variation between groups and higher scores for residents and non-oculoplastic specialists compared to the previous results (Table 3).

\section{Discussion}

Although histopathological examination is considered the gold standard in the diagnosis of tumours, clinical examination remains important for ensuring correct treatment and an 
Table 1

Accuracy in diagnosing malignant lesions versus experience and specialisation in oculoplastic surgery

\begin{tabular}{lcccccc}
\hline Group & Accuracy & Sensitivity & Specificity & PPV & NPV & Kappa \\
\hline $\mathbf{1}$ & 64.5 & 70.8 & 44.2 & 80.6 & 31.5 & 0.13 \\
& $(62.1-67.0)$ & $(64.7-76.3)$ & $(32.8-55.9)$ & $(74.8-85.6)$ & $(22.9-41.1)$ & $(0.02-0.24)$ \\
$\mathbf{2}$ & 69.2 & 73.4 & 55.4 & 84.4 & 38.8 & 0.25 \\
& $(66.5-71.9)$ & $(66.4-79.6)$ & $(41.5-68.7)$ & $(77.8-89.6)$ & $(28.1-50.3)$ & $(0.12-0.38)$ \\
$\mathbf{3}$ & 67.9 & 71.1 & 57.1 & 84.5 & 37.6 & 0.24 \\
& $(65.5-70.2)$ & $(65.1-76.6)$ & $(45.4-68.4)$ & $(78.9-89.1)$ & $(28.8-47.0)$ & $(0.13-0.35)$ \\
$\mathbf{4}$ & 71.7 & 72.4 & 69.4 & 88.6 & 43.3 & 0.35 \\
& $(69.7-73.6)$ & $(67.1-77.2)$ & $(59.3-78.3)$ & $(84.1-92.2)$ & $(35.4-51.4)$ & $(0.25-0.44)$ \\
$\mathbf{5}$ & 77.3 & 77.3 & 74.3 & 90.9 & 51.0 & 0.45 \\
& $(74.5-80.1)$ & $(69.6-85.4)$ & $(56.7-87.5)$ & $(83.4-95.8)$ & $(36.6-65.2)$ & $(0.30-0.61)$ \\
$\mathbf{6}$ & 74.4 & 75.0 & 72.3 & 89.9 & 46.8 & 0.40 \\
& $(72.7-76.1)$ & $(70.2-79.3)$ & $(63.1-80.4)$ & $(86.0-93.0)$ & $(39.2-54.5)$ & $(0.31-0.48)$ \\
$\mathbf{7}$ & 64.8 & 65.5 & 62.2 & 85.1 & 35.5 & 0.22 \\
& $(62.6-66.9)$ & $(60.1-70.7)$ & $(51.9-71.8)$ & $(80.0-89.3)$ & $(28.3-43.1)$ & $(0.13-0.31)$ \\
$\mathbf{8}$ & 69.2 & 69.6 & 67.9 & 87.7 & 40.4 & 0.30 \\
& $(66.5-71.9)$ & $(62.4-76.1)$ & $(54.0-79.7)$ & $(81.2-92.5)$ & $(30.4-51.0)$ & $(0.18-0.42)$ \\
$\mathbf{9}$ & 62.3 & 60.4 & 68.4 & 86.3 & 34.5 & 0.22 \\
& $(60.4-64.2)$ & $(55.7-65.0)$ & $(59.8-76.2)$ & $(81.9-89.9)$ & $(28.8-40.5)$ & $(0.14-0.29)$ \\
Overall & 68.2 & 69.6 & 63.9 & 86.4 & 39.0 & 0.27 \\
& $(67.5-69.0)$ & $(67.7-71.4)$ & $(60.3-67.3)$ & $(84.8-87.8)$ & $(36.2-41.8)$ & $(0.24-0.31)$ \\
\hline
\end{tabular}

Table 2

\section{Accuracy in diagnosing the histological tumour type versus experience and specialisation in oculoplastic surgery}

\begin{tabular}{lcc}
\hline Group & Accuracy (\%) & $\begin{array}{c}\text { Confidence } \\
\text { Interval } \mathbf{( 9 5} \%)\end{array}$ \\
\hline $\mathbf{1}$ & 51,1 & $47,5-54,8$ \\
$\mathbf{2}$ & 64,0 & $60,1-67,8$ \\
$\mathbf{3}$ & 59,4 & $55,9-63,0$ \\
$\mathbf{4}$ & 68,2 & $65,5-71,0$ \\
$\mathbf{5}$ & 72,2 & $68,1-76,4$ \\
$\mathbf{6}$ & 77,2 & $75,1-79,3$ \\
$\mathbf{7}$ & 58,3 & $55,0-61,6$ \\
$\mathbf{8}$ & 68,8 & $65,0-72,5$ \\
$\mathbf{9}$ & 53,4 & $50,4-56,4$ \\
Overall & 63,3 & $62,2-64,4$ \\
\hline
\end{tabular}

improved prognosis. ${ }^{(1,2)}$ However, lesion presentation and appearance are very variable, and there can be similarities between benign and malignant lesions. ${ }^{(3)}$

Various benign and malignant tumours can develop in the periocular skin, arising from the epidermis, the dermis or the annexes. The appearance and behaviour of eyelid lesions can be different from lesions appearing elsewhere in the body, in part due to the specific characteristics of the eyelid skin and its specialised annexes. Ophthalmologists are therefore frequently responsible for diagnosing and treating such lesions, and the first priority should be to rule out a malignancy. ${ }^{(4)}$ Another important consideration is that the healthy peritumoural tissues should be damaged as little as possible in order to preserve their function and avoid disfiguration. ${ }^{(3)}$
The most common benign periocular lesions are chalazion, seborrhoeic keratosis, epidermoid cyst, and hidrocystoma, whereas the most common malignant lesions are BCC and SCC. (1-6) On examination it is important to assess the pigmentation, borders and texture of lesions, as pearly lesions are suggestive of BCC. It is also important to assess the presence of madarosis, which, despite being a weak isolated indicator of malignancy, is more common in malignant than benign lesions. When madarosis is present, there is a $69.23 \%$ chance of malignancy, and the risk is 13.4 times higher. In spite of this relationship, its presence is not a definitive indicator of malignancy, nor does its absence guarantee that the lesion is benign. It is therefore important to consider other signs suggesting malignancy, such as telangiectasias, ulcers, spontaneous bleeding, changes in eyelid anatomy, and recurrent lesions. It is also important to assess determine when the lesion appeared and its growth pattern, as older lesions that do not increase in size are less suspicious. Furthermore, patients with lighter skin as measured by the Fitzpatrick scale are more susceptible to sunburn and therefore have a higher risk of developing skin cancer. A history of excessive sun exposure, advanced age, immunosuppression, and smoking should also be taken into account. (5)

According to the literature, the accuracy of the clinical diagnosis of eyelid malignancies is between 65 and $96 \%$. Our results fall within that range (mean: $68.2 \%$, best group: $77.3 \%$ ). The sensitivity and specificity found in our study were lower than in other studies, even though our mean PPV was high (86\%). These values can be explained in part by the study design, as participants only had access to printed images, which can affect the sensitivity and specificity of diagnosis. Some authors consider that PPV is more important and less subject to variation than the other two indicators. ${ }^{(1,7)}$ 
Table 3

\section{Estimates (\%) and $95 \%$ confidence intervals (Cl) for tumour aggressiveness versus} experience and specialisation in oculoplastic surgery

\begin{tabular}{lcccccc}
\hline Group & Accuracy & Sensitivity & Specificity & PPV & NPV & Kappa \\
\hline $\mathbf{1}$ & 72.2 & 84.8 & 51.5 & 74.2 & 67.3 & 0.38 \\
& $(69.3-75.2)$ & $(76.8-90.9)$ & $(39.0-63.8)$ & $(65.7-81.5)$ & $(52.9-79.7)$ & $(0.24-0.52)$ \\
$\mathbf{2}$ & 74.3 & 85.1 & 61.3 & 72.4 & 77.6 & 0.47 \\
& $(71.1-77.5)$ & $(75.0-92.3)$ & $(48.1-73.4)$ & $(61.8-81.5)$ & $(63.4-88.2)$ & $(0.33-0.62)$ \\
$\mathbf{3}$ & 73.3 & 82.2 & 60.3 & 75.2 & 69.8 & 0.44 \\
& $(70.5-76.2)$ & $(73.7-89.0)$ & $(48.1-71.5)$ & $(66.4-82.7)$ & $(57.0-80.8)$ & $(0.30-0.57)$ \\
$\mathbf{4}$ & 75.1 & 79.4 & 70.1 & 75.8 & 74.3 & 0.50 \\
& $(72.7-77.5)$ & $(71.2-86.1)$ & $(60.5-78.6)$ & $(67.5-82.8)$ & $(64.6-82.8)$ & $(0.39-0.61)$ \\
$\mathbf{5}$ & 73.9 & 86.5 & 55.6 & 73.8 & 74.1 & 0.44 \\
& $(69.8-77.9)$ & $(74.2-94.4)$ & $(38.1-72.1)$ & $(60.9-84.2)$ & $(53.7-88.9)$ & $(0.25-0.63)$ \\
$\mathbf{6}$ & 75.8 & 73.3 & 78.3 & 76.7 & 75.0 & 0.52 \\
& $(73.6-78.0)$ & $(65.0-80.6)$ & $(70.4-84.8)$ & $(68.5-83.7)$ & $(67.1-81.8)$ & $(0.42-0.62)$ \\
$\mathbf{7}$ & 75.4 & 87.6 & 58.9 & 74.1 & 77.9 & 0.48 \\
& $(72.8-77.9)$ & $(80.4-92.9)$ & $(48.0-69.2)$ & $(66.1-81.1)$ & $(66.2-87.1)$ & $(0.36-0.60)$ \\
$\mathbf{8}$ & 76.6 & 82.4 & 70.0 & 75.7 & 77.8 & 0.53 \\
& $(73.5-79.7)$ & $(71.2-90.5)$ & $(56.8-81.2)$ & $(64.3-84.9)$ & $(64.4-88.0)$ & $(0.38-0.67)$ \\
$\mathbf{9}$ & 71.5 & 86.6 & 51.4 & 70.5 & 74.0 & 0.40 \\
& $(69.1-74.0)$ & $(80.0-91.6)$ & $(41.7-61.0)$ & $(63.3-77.0)$ & $(62.8-83.4)$ & $(0.28-0.51)$ \\
Overall & 74.2 & 82.7 & 63.4 & 74.1 & 74.3 & 0.47 \\
& $(73.3-75.1)$ & $(80.2-85.1)$ & $(59.8-66.8)$ & $(71.3-76.7)$ & $(70.7-77.7)$ & $(0.43-0.51)$ \\
\hline
\end{tabular}

Most studies on the accuracy of clinical diagnosis in eyelid tumours are retrospective studies based on data from pathological examination. As there is a natural tendency to only submit suspected malignant lesions for pathological examination, retrospective studies cannot precisely evaluate diagnostic accuracy. ${ }^{(8)}$

Previous studies evaluated the clinical accuracy of one, two, four, or more examiners. ${ }^{(1,3,4,8)}$ This number can influence results. For example, Kersten et al. found a high sensitivity in the clinical diagnosis of malignant lesions based on the experience of one very highly skilled professional. ${ }^{(8)}$ This increases the internal validity of the study, but decreases its external validity because its results are less reproducible.

In studies assessing the ability of various specialists (dermatologists, plastic surgeons, general practitioners, and paediatricians) to diagnose skin lesions, dermatologists diagnosed the highest number of malignant and pre-malignant lesions, followed by plastic surgeons. ${ }^{(9,10)}$ Several studies also found that dermatologists had the best results in the clinical diagnosis of melanoma. ${ }^{(9)}$

Furthermore, accuracy was found to increase with greater professional experience, as was the case in the present study. ${ }^{(2,8,11)}$

The accuracy of participants in determining the histological type of tumours was lower than in determining the presence of a malignancy, as shown in Tables 1 and 2. Of all malignant eyelid tumours, diagnostic accuracy was highest for BCC at $89 \%$. Kersten reports an accuracy of $92.8 \%$ for the clinical diagnosis of BCC, corresponding to $90 \%$ of all lesions shown to be malignant. ${ }^{(4)}$

The ability to diagnose a BCC is also related to professional experience. Presser et al. evaluated the accuracy of the clinical diagnosis of BCC by resident dermatologists, dermatologists working in private practices and university professors and found indices of $64 \%, 65 \%$ and $70 \%$ respectively. For first-, secondand third-year residents, diagnostic accuracy was 56\%, 59\% and $73 \%$ respectively. ${ }^{(12)}$

Diagnostic accuracy tends to be lower for SCC, at approximately $36 \%$. $^{(2,3,8,9)}$

The mortality rate of melanoma has made it the focus of increased attention. According to Boiko et al., $75 \%$ of general practitioners and $50 \%$ of consulting physicians can fail to diagnose a melanoma. ${ }^{(13)}$

It should be noted that sebaceous gland carcinoma is one of the tumours most commonly misdiagnosed as benign (being confused with chalazion). ${ }^{(14)}$

This study found that residents (starting their professional life) and more experienced physicians who are not specialised in oculoplastic surgery (Tables 1 e 2) had the lowest diagnostic accuracy. This stresses the need to improve knowledge of eyelid oncology among these groups.

The assessment of tumour aggressiveness was a source of confusion as there was practically no difference between groups, while in theory this question should have produced results consistent with the other items.

Most studies in the literature are retrospective, assessing a number of lesions submitted by different medical professionals to several laboratories. ${ }^{(4)}$ In our study, all ophthalmologists were presented with the same lesions, but the fact that they only had access to printed images of those lesions may have been a limiting factor, as examination with a slit lamp or dermatoscope could facilitate diagnosis. Furthermore, participants did not have access to the patients' clinical history or other data which are important for clinical diagnosis. This could also lead to an overestimation of the number of malignancies, as when in doubt practitioners tend to consider the worst case scenario. ${ }^{(15,16)}$

In this study, the fact that all participants evaluated the 
same lesions makes their assessments more comparable, which was not the case in other studies where each lesion was assessed by a single professional.

\section{Conclusion}

Clinical examination, the first evaluation of a patient, plays an important role in the detection and treatment of eyelid lesions, both benign and malignant. These lesions can have very different presentations, therefore clinical suspicion, based on the professional's experience, can help guide treatment and determine the prognosis. Ophthalmologists are frequently responsible for diagnosing and treating eyelid tumours. Our study found overall accuracy rates in the diagnosis of malignant lesions similar to other studies in the literature. However, participants were less accurate in diagnosing the histological type of each lesion. Results on the ability of participants to diagnose aggressive lesions were inconclusive. The least accurate groups were residents at the start of the profession and ophthalmologists not specialised in oculoplastic surgery. This finding is important as it can inform initiatives aimed at improving the knowledge of eyelid oncology among these groups. Furthermore, our results confirm that ophthalmologists specialised in oculoplastic surgery, given their greater familiarity and more frequent contact with such lesions, tend to have greater rates of accuracy, although these can still be improved with continuous training.

\section{ReFERENCES}

1. Har-Shai Y,Hai N, Taran A, Mayblum S, Barak A, Tzur E, et al. Sensitivity and positive predictive values of presurgical clinical diagnosis of excised benign and malignant skin tumors: a prospective study of 835 lesions in 778 patients. Plast Reconstr Surg. 2001; 108(7):1982-9.

2. Ek EW, Giorlando F, Su SY, Dieu T. Clinical diagnosis of skin tumours: how good are we? ANZ J Surg. 2005;75(6):415-20.
3. Hallock GG, Lutz DA. Prospective study of the accuracy of the surgeon's diagnosis in 2000 excised skin tumors. Plast Reconstr Surg. 1998;101(5):1255-61.

4. Kersten RC,Ewing-Chow D, Kulwin DR, Gallon M. Accuracy of clinical diagnosis of cutaneous eyelid lesions. Ophthalmology. 1997;104(3):479-84.

5. Groehler JM, Rose JG. Madarosis as an indicator for malignancy in eyelid margin lesions. optometry and vision science. 2012; 89(3):350-2.

6. Margo CE. Eyelid tumors: accuracy of clinical diagnosis. Am J Ophthalmol. 1999;128(5):635-6.

7. Guggenmoos-Holzmann I, van-Houwellingen HC. The in(validity) of sensitivity and specificity. Stat Med. 2000; 19(13):1783-92.

8. Deokule S, Child V, Tarin S, Sandramouli S. Diagnostic accuracy of benign eyelid skin lesions in the minor operation theatre. Orbit. 2003;22(4):235-8.

9. Matteucci P, Pinder R, Magdum A, Stanley P. Accuracy in skin lesion diagnosis and the exclusion of malignancy. J Plast Reconstr Aesthet Surg. 2011;64(11):1460-5.

10. Sellheyer K, Bergfeld WF. A retrospective biopsy study of the clinical diagnostic accuracy of common skin diseases by different specialties compared with dermatology. J Am Acad Dermatol. 2005;52(5):823-30

11. Osborne JE, Chave TA, Hutchinson PE. Comparison of diagnostic accuracy for cutaneous malignant melanoma between general dermatology, plastic surgery and pigmented lesion clinics. Br J Dermatol. 2003;148(2):252-8.

12. Presser SE, Taylor JR. Clinical diagnostic accuracy of basal cell carcinoma. J Am Acad Dermatol. 1987;16(5 Pt 1):988-90.

13. Boiko PE, Koepsell TD, Larson EB, Wagner EH. Skin cancer diagnosis in a primary care setting. J Am Acad Dermatol. 1996;34(4):608-11.

14. Ozdal PC, Codère F, Callejo S, Caissie AL, Burnier MN. Accuracy of the clinical diagnosis of chalazion. Eye (Lond). 2004;18(2):135-8.

15. Heal CF, Raasch BA, Buettner PG, Weedon D. Accuracy of clinical diagnosis of skin lesions. Br J Dermatol. 2008;159(3):661-8.

16. Moffatt CR, Green AC, Whiteman DC. Diagnostic accuracy in skin cancer clinics: the Australian experience. Int J Dermatol. 2006;45(6):656-60.

\section{Corresponding author:}

Luiz Angelo Rossato

Av Adhemar Pereira de Barros, 745

CEP 86050-190, Londrina/PR, Brazil.

E-mail: luiz_rossato@hotmail.com 